\title{
APLIKASI MONITORING PRAKTEK KERJA INDUSTRI PESERTA DIDIK SMK MUTIARA BANGSA BERBASIS ANDROID
}

\author{
Ana Noviana \\ Program Studi Teknik Informatika, Fakultas Teknik dan Ilmu Komputer, \\ Universitas Indraprasta PGRI \\ Jalan Raya Tengah No 80, Kelurahan Gedong, Pasar Rebo, Jakarta Timur \\ anna.noviana23@gmail.com
}

\begin{abstract}
Abstrak
Tujuan penelitian ini adalah upaya untuk mengontrol kegiatan/aktifitas peserta dalam pelaksanaan praktek kerja industri (prakerin), upaya monitoring ini terjadi karena banyaknya peserta didik dan guru pembimbing yang melakukan kecurangan dengan tidak hadir/datang ke perusahaan, maka peneliti merancang sistem monitoring praktek kerja industri (Prakerin) berbasis android. Pembuatan sistem ini menggunakan bahasa pemrograman java, XML dan database MySQL. Metodologi penelitian yang digunakan dalam sistem pengolahan data yaitu teknik pengumpulan data seperti wawancara dengan pihak terkait yaitu kepala program studi, peserta didik dan guru pembimbing, melihat buku agenda/jurnal peserta prakerin dan laporanlaporan lainnya dan melakukan dokumentasi untuk mendapatkan informasi yang dibutuhkan. Peneliti juga melakukan penelitian dengan metode kepustakaan yang relevan dengan masalah sistem monitoring praktek kerja industri (Prakerin). Setelah melakukan penelitian dan analisa permasalahan serta menyelesaikan masalah yang diusulkan, maka peneliti dapat menyimpulkan bahwa, sistem yang berjalan masih dilakukan dengan aplikasi sederhana menggunakan aplikasi Microsoft Office dengan dibangunnya sistem monitoring praktek kerja industri (Prakerin) ini diharapkan pada SMK Mutiara Bangsa bisa mempermudah sistem monitoring praktek kerja industri (Prakerin) yang dapat mengolah data praktek kerja industri (Prakerin) secara menyeluruh, serta menghasilkan sebuah informasi evaluasi praktek kerja industri (Prakerin) untuk pihak sekolah.
\end{abstract}

Kata Kunci: Aplikasi, Monitoring, Praktek Kerja Industri, Peserta Didik SMK, Android.

\begin{abstract}
The purpose of this study is an effort to control the activities of participants in the implementation of industrial work practices, this monitoring effort occurs because many students and supervisors are cheating by not attending / coming to the company, so the researchers designed a monitoring system for industrial work practices. Based on android, Making this system using the Java programming language, XML and MySQL database. The research methodology used in the data processing system is data collection techniques such as interviews with related parties, namely the head of the study program, students and supervisors, looking at the internship participant's agenda book, journal and other reports and carrying out documentation to get the information needed. Researchers also conducted research using literature methods that are relevant to the problem of industrial work practices monitoring system. After conducting research and analyzing problems and solving the proposed problems, the researchers can conclude that, the running system is still carried out with a simple application using the Microsoft Office application with the construction of an industrial work practice monitoring system, it is hoped that SMK Mutiara Bangsa can simplify the monitoring system. industrial work practice which can process industrial work practice data as a whole, as well as produce an evaluation of industrial work practice information for the school.
\end{abstract}

Keyword: Application, Monitoring, Industrial Work Practices, Vocational Students, Android.

\section{PENDAHULUAN}

Android merupakan salah satu sistem operasi yang banyak digunakan pada saat ini. Smartphone berbasis android sangat membantu user dalam melakukan berbagai aktivitas seperti belajar, berbelanja online, berkomunikasi, presentasi, dan masih banyak lagi. Android menurut (Safaat, 2011) adalah sistem operasi untuk smartphone berbasis linux yang mencakup sistem operasi, middleware dan aplikasi. Android adalah platform terbuka yang memungkinkan pengembang menciptakan aplikasi mereka. Android didistribusikan dengan dua jenis. Pertama yang mendapat 
dukungan penuh dari google atau Google Mail Service (GMS). Kedua adalah yang tidak mendapatkan dukungan secara langsung dari google atau Open Handset Distribution (OHD).

Menurut (Abdurahman, H., \& Riswaya, 2014) Aplikasi adalah suatu program yang bisa digunakan untuk menjalankan perintah dari pengguna aplikasi tersebut dengan tujuan mendapatkan hasil yang lebih akurat, cepat dan lebih mudah sesuai dengan tujuan pembuatan aplikasi tersebut, aplikasi mempunyai arti pemecahan masalah yang menggunakan salah satu teknik pemrosesan data, aplikasi biasanya berpacu pada sebuah program untuk mendapat hasil yang diinginkan atau diharapkan.

Untuk memenuhi kebutuhan dan tuntutan di atas penulis mencoba membuat program aplikasi prakerin berbasis android yang dapat dengan mudah dipakai oleh para pengguna smartphone khususnya peserta didik SMK.

Software ini dibuat dengan menggunakan aplikasi android studio. Android Studio merupakan sebuah software tools Integrated Development Environtment (IDE) untuk platform Android. Android Studio ini diluncurkan pada tanggal 16 Mei 2013 pada konferensi Google I/O oleh Produk Manajer Google, Ellie Powers (Yudhanto, 2018).

Praktek kerja industri (prakerin) adalah salah satu kurikulum SMK dalam melaksanakan pembelajaran untuk memberikan pengalaman kepada peserta didik kelas XI di semester genap selama 1 sampai 3 bulan. Hal ini menjadi kendala bagi SMK Mutiara Bangsa yang memiliki peserta didik dari berbagai tempat apabila peserta didik memilih sendiri tempat prakerin. SMK Mutiara Bangsa akan kesulitan dalam memonitoring/memantau siswa dalam melaksanakan prakerin. Apabila dari pihak guru pembimbing tidak memantau peserta didik dalam kegiatan prakerin dan hanya mengacu pada buku kegiatan harian yang diberikan maka siswa tidak akan disiplin dan tidak sungguh-sungguh dalam melaksanakan prakerin sehingga tujuan sekolah dalam memberikan pengalaman kerja didunia nyata tidak tercapai dengan baik.

Menurut (Gudda, 2011) Monitoring (pemantauan) adalah seni mengumpulkan informasi yang diperlukan dengan usaha minimal untuk membuat keputusan pada saat yang tepat. Monitoring praktek kerja industri (prakerin) adalah prosedur untuk pengawasan terhadap pelaksanaan praktek kerja industri peserta didik sesuai jadwal yang telah disetujui oleh kepala program, peserta mengisi buku jurnal dan mencatat kegiatan harian, proses pelaksanaan monitoring oleh guru pembimbing sampai dengan kegiatan prakerin selesai dengan adanya laporan dokumen prakerin.

\section{PENELITIAN RELEVAN}

Penelitian ini diambil dari jurnal (Ningsih et al., 2012) dengan judul Rancang Bangun Sistem Informasi Praktek Kerja Industri Berbasis Web (Studi Kasus : SMK Al- Azhar Menganti Gresik) dengan hasil penelitian bahwa SMK Al- Azhar Menganti Gresik selama penyajian dan pengolahan masih manual sehingga pihak administrasi prakerin kesulitan dalam mengolah data prakerin untuk menentukan jadwal prakerin dan tempat prakerin yang sesuai dengan kriteria siswa dan kualifikasi dari perusahaan.. Data relavan tersebut menjadi bahan penelitian untuk mengembangkan penelitian dimana sebelumnya terdapat perbedaan seperti metode perancangan sistem, bahasa pemrograman, dan hasil aplikasinya berupa sebuah website. Sedangkan penelitian ini dikembangkan berbasis smartphone dengan sistem operasi Android yaitu menggunakan Android Studio dan database MySQL. Perbedaan dari penelitian ini adalah aplikasi monitoring untuk siswa dan guru berupa aplikasi yang terinstal di smartphone sehingga memudahkan guru pembimbing dan siswa untuk mengisi laporan kegiatan praktek kerja industri. Fitur dari aplikasi hampir memiliki kesamaan sesuai dengan kebutuhan kegiatan prakerin hanya saja di penelitian ini hasil dari kegiatan prakerin, siswa bisa mengunduh sertifikasi prakerin jika sudah divalidasi oleh guru pembimbing dan pihak sekolah.

Penelitian selanjutnya diambil dari penelitian jurnal oleh (Putra et al., 2019) dengan judul Pengembangan Sistem Pengelolaan Praktik Kerja Industri pada Sekolah Menengah Kejuruan (Studi Kasus : SMK PGRI 3 malang). Hasil penelitian tersebut yaitu menyelesaikan manajemen prakerin pada tahap penempatan, monitoring dan penilaian kepada siswa sehingga sangat relavan dijadikan bahan penelitian ini. Pengembangan dari penelitian yang ada di SMK PGRI 3 adalah berupa aplikasi antarmuka dengan menggunakan HTML, CSS serta Javascript atau aplikasi berbasis website. Dengan adanya aplikasi ini BKI (Bidang Kerjasama Industri ) dapat mengelola kegiatan PKL dengan baik. 
Penelitian lainnya oleh (Gani \& Baye, 2018) yang menjadi bahan untuk peneliti yaitu jurnal dengan judul Sistem Informasi Praktek Kerja Industri pada SMK Islam Sirajul Huda Paok Dandak. Pada penelitian ini dikembangkan sistem informasi praktek kerja industri berbasis web SMK Sirajul Huda Paok Dandak. Metode analisis menggunakan metode PIECES, Metode perancangan menggunakan Unifed Modeling Language (UML), desain interface menggunakan CSS, Javascript, Dreamweaver, dan Exampp sebagai database server. Sistem informasi ini memberikan informasi kepada siswa peserta praktek kerja industri tentang format laporan kegiatan Prakerin, jadwal kunjungan guru pembimbing, dan informasi waktu berakhir kegiatan Prakerin. Hasil penelitian ini menunjukkan sistem informasi praktek kerja industri SMK Sirajul Huda memberikan kemudahan dalam penyampaian informasi kepada siswa peserta praktek kerja Industri. Perbedaan dari penelitian ini adalah aplikasi masih berbasis website.

\section{METODE PENELITIAN}

Metode penelitian yang dilakukan oleh peneliti merupakan jenis penelitian pengembangan atau Research and Development (R\&D). Menurut (Nana Syaodih Sukmadinata, 2010) Penelitian R\&D adalah suatu proses atau langkah-langkah untuk mengembangkan suatu produk baru atau menyempurnakan produk yang telah ada. Berikut metode yang peneliti antara lain adalah:

\section{a. Metode Pengumpulan data}

Menurut (Sugiyono, 2012) teknik pengumpulan data merupakan langkah yang paling strategis dalam penelitian, karena tujuan utama dari penelitian adalah mengumpulkan data.

1) Observasi

Yaitu mengumpulkan data-data dengan melakukan pengamatan terhadap proses kerja yang ada pada bagian kepala program SMK serta melakukan pengamatan pada sistem berjalan.

2) Studi Literatur

Pada tahap ini melakukan pencarian dan pengumpulan literatur-literatur yang berhubungan dengan masalah dalam pembangunan sistem monitoring prakerin berbasis android ini dari buku referensi yang menunjang.

3) Wawancara

Yaitu melakukan pengumpulan data dengan diadakannya tanya jawab dan tinjauan kepada berbagai pihak mengenai masalah yang ada hubungannya dengan penelitian ini.

\section{b. Langkah-langkah Pengembangan Sistem}

Dalam membuat langkah-langkah pengembangan sistem, penulis menggunakan metode terstruktur dengan Paradigma Waterfall Model atau Classic Life Cicle. Menurut (Bassil, 2012) disebut waterfall karena tahap demi tahap yang harus dilalui menunggu selesainya tahap sebelumnya dan berjalan berurutan.

Berikut penjelasan aktivitas dan setiap tahapan Paradigma Siklus Hidup Klasik yang diterapkan pada Aplikasi Sistem Monitoring Praktek Kerja Industri Peserta Didik SMK Mutiara Bangsa berbasis Android, adalah:

1) Rekayasa Sistem, merupakan tahap awal dari pembangunan perangkat lunak, yaitu menetapkan segala hal yang diperlukan dalam pelaksanaan pembangunan perangkat lunak dan menentukan apakah sistem benar-benar dibutuhkan. Aplikasi monitoring praktek kerja industri peserta didik SMK dirancang dengan bahasa pemrograman Android, PHP dan HTML, sedangkan untuk database menggunakan MySQL.

2) Analisis, merupakan tahap dimana rekayasa perangkat lunak menganalisis hal-hal yang diperlukan dalam pelaksanaan. Analisis yang digunakan menggunakan Unified Modelling Language (UML) yang meliputi Use Case Diagram atau model fungsional dari aplikasi monitoring praktek kerja industri peserta didik SMK, Activity diagram, Sequence Diagram, Class Diagram.

3) Desain, merupakan tahap penterjemahan dari keperluan data-data yang telah dianalisis kedalam bentuk yang mudah dimengerti oleh pemakai. Desain aplikasi 
monitoring praktek kerja industri peserta didik SMK meliputi perancangan basis data, rancangan layar, rancangan form masukan data dan rancangan keluaran.

4) Coding, adalah tahap penterjemahan data pemecah masalah yang telah dirancang kedalam bahasa pemograman komputer yang telah ditentukan. Coding dalam pengembangan aplikasi monitoring praktek kerja industri peserta didik SMK menggunakan bahasa pemrograman Android Studio, PHP dan HTML, sedangkan untuk database menggunakan MySQL.

5) Testing, merupakan tahap pengujian terhadap perangkat lunak yang telah selesai dibuat untuk menemukan kesalahan-kesalahan atau kekurangan yang terdapat di dalam sistem. Pada pengujian ini penulis menggunakan pengujian black box . Pengujian black box adalah pengujian aspek fundamental sistem tanpa memperhatikan struktur logika internal perangkat lunak. Metode ini digunakan untuk mengetahui apakah perangkat lunak berfungsi dengan benar. Pengujian black box merupakan metode perancangan data uji yang didasarkan pada spesifikasi perangkat lunak. Data uji dieksekusi pada perangkat lunak dan kemudian keluar dari perangkat lunak dicek apakah telah sesuai dengan yang diharapkan.

6) Maintenance, yaitu tahap akhir dimana perangkat lunak yang sudah selesai dan mengalami perubahan atau penambahan sesuai dengan permintaan. Bagian ini merupakan bagian terujung dari siklus pengembangan sistem laporan produksi. Pada tahapan ini dilakukan kegiatan corrective maintenance, yaitu mengkoreksi kesalahan pada perangkat lunak yang baru diketahui pada saat perangkat lunak dipergunakan. Dengan adanya corrective maintenance terhadap sistem laporan, maka kesalahan-kesalahan yang terdapat pada informasi hasil produksi ini dapat diperbaiki.

\section{HASIL DAN PEMBAHASAN}

\section{Alternatif Penyelesaian Masalah}

Melihat dari permasalahan yang ada maka peneliti membuat suatu proses penyelesaian dengan membuat aplikasi untuk menangani kegiatan praktek kerja industri (Prakerin) berbasis android, yang mana aplikasi yang penulis lakukan memiliki fitur sebagai berikut:

1) Kepala program dapat melakukan input data peserta didik, guru pembimbing serta jadwal prakerin secara online.

2) Peserta didik melakukan absensi kehadiran di tempat prakerin secara online melalui aplikasi prakerin yang diinstal di smartphone.

3) Peserta didik dapat secara langsung mengisi kegiatan harian prakerin dengan hanya mengisi topik kegiatan dan mengupload dokumen gambar kegiatan.

4) Guru pembimbing dapat memantau absensi kehadiran peserta didik dan kegiatan kapanpun.

5) Guru pembimbing dapat mengisi laporan kunjungan monitoring ke tempat prakerin.

6) Jika status jadwal pada peserta didik telah diubah selesai oleh guru pembimbing dan daftar nilai telah diupload maka siswa dapat mencetak sertifikat prakerin. 


\section{Unified Modelling Language (UML) \\ Use Case Diagram}

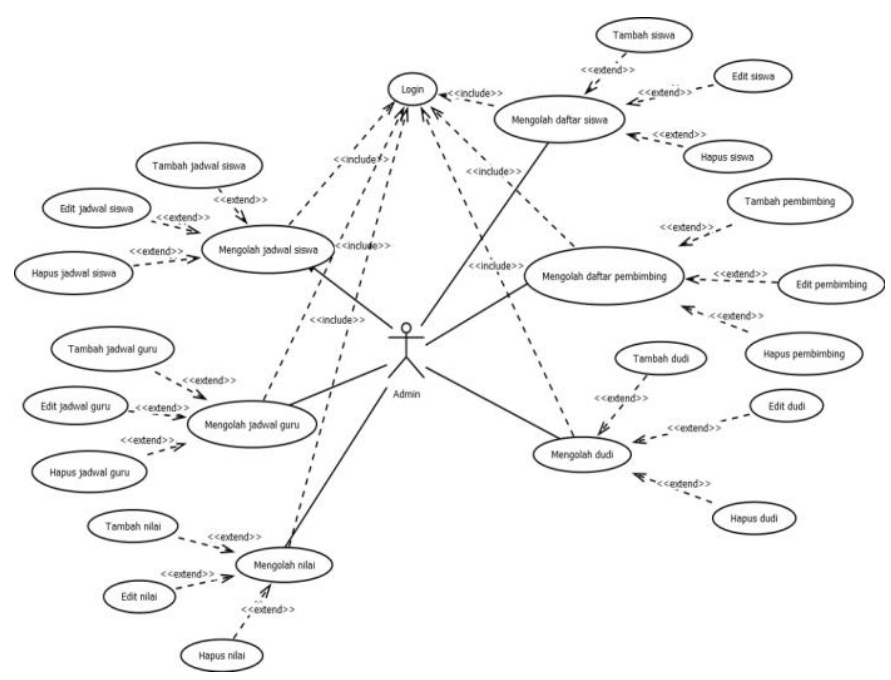

Gambar 1. Use Case Diagram Admin

Admin sebagai penyelia bertugas untuk mengelola data seperti data siswa, guru, dudi, dan jadwal.

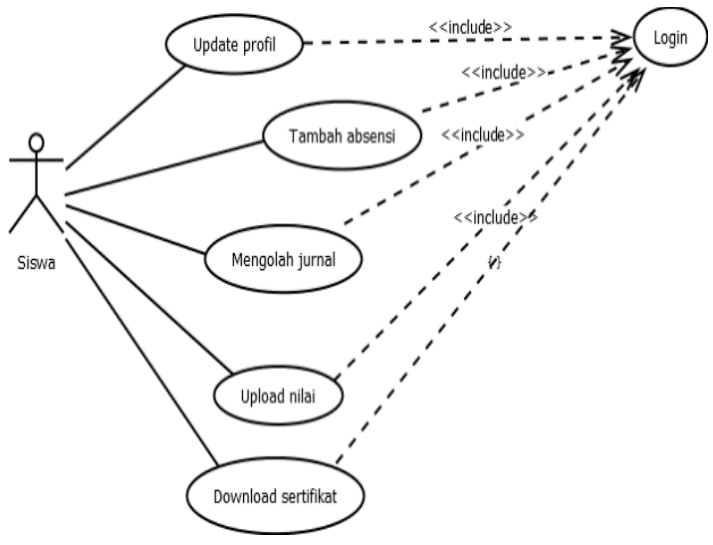

Gambar 2. Use Case Diagram Siswa

Siswa sebagai peserta prakerin bertugas untuk update profil, mengisi absensi, isi jurnal dan mengunduh sertifikat prakerin.

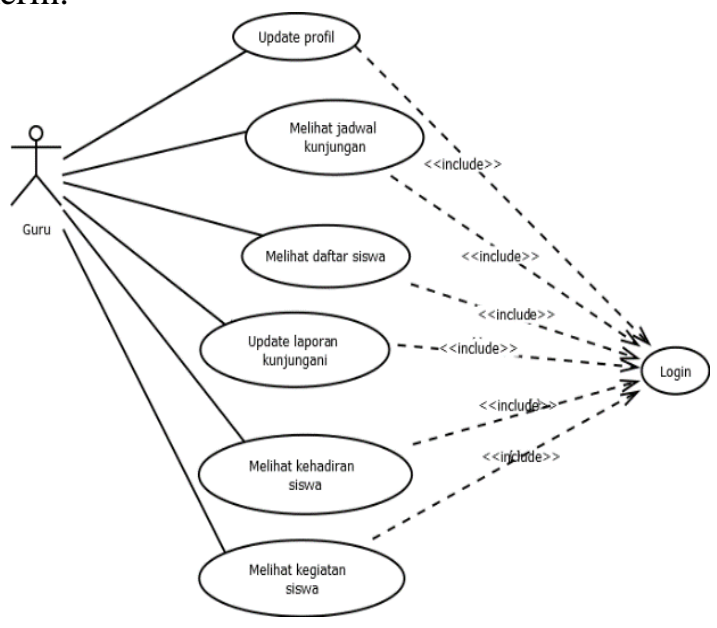

Gambar 3. Use Case Diagram Pembimbing

Guru sebagai pembimbing prakerin bertugas untuk mengecek jadwal kunjungan, daftar siswa, mengisi laporan, monitoring kehadiran dan kegiatan siswa. 


\section{Interface}

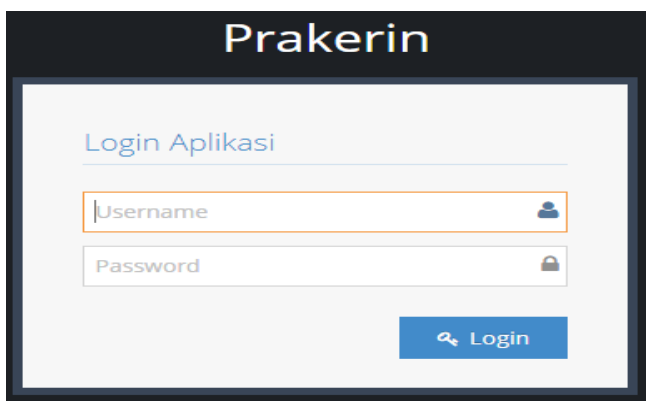

Gambar 4. Tampilan Halaman Login

Pada bagian tampilan halaman login digunakan untuk siswa dan guru masuk ke dalam sistem dan terdapat menu-menu yang akan dipilih selanjutnya.

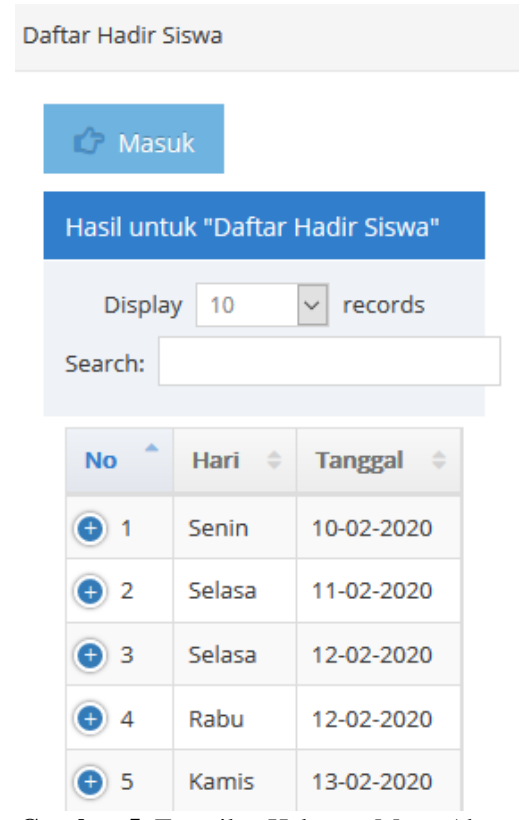

Selanjutnya pada halaman menu absen siswa. Setiap hari siswa absen dengan klik tombol masuk dan keluar.

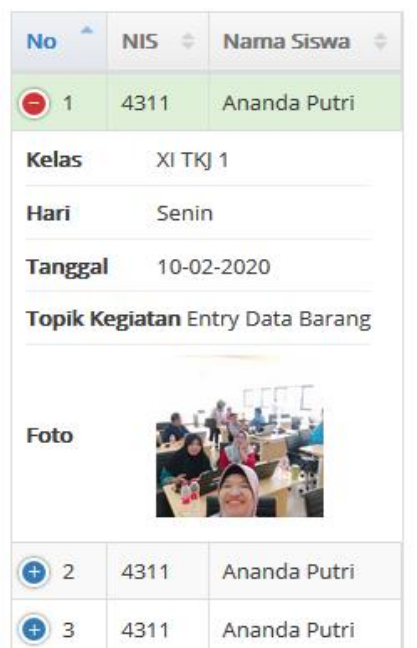

Gambar 6. Halaman Monitoring Kegiatan Siswa 
Dan tampilan halaman monitoring kegiatan siswa oleh guru sebagai proses pemantauan kegiatan yang dilakukan siswa selama melaksanakan prakerin.

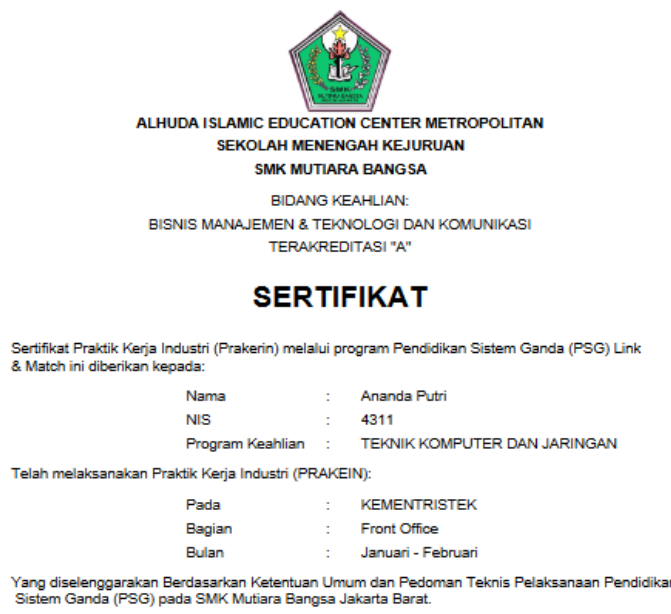

Jakarta, 27 Februari 2020
Kepala SMK Mutiasa Banga

ADE NOVIAWATY, M.Pd

Gambar 7. Tampilan Sertifikat Prakerin

Sertifikat prakerin yang bisa diunduh oleh siswa jika sudah divalidasi oleh guru pembimbing dan penyelia prakerin sekolah
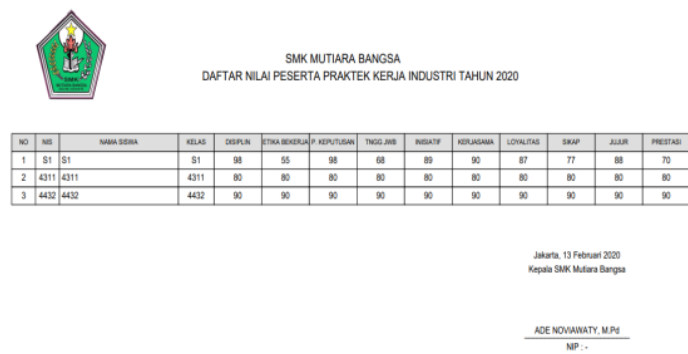

Gambar 8. Tampilan Laporan Nilai

Laporan hasil nilai siswa selama kegiatan prakerin dan akan masukan ke dalam sistem raport kenaikan kelas.

\section{Uji Coba di Perangkat Smartphone}

Uji Coba dengan perangkat dilakukan untuk melihat kekurangan dari aplikasi jika di jalankan dengan

perangkat smartphone. Dari uji coba yang sudah dilakukan berikut kesimpulan hasil yang didapat dari proses uji coba:

Tabel 1. Uji coba program dengan Smartphone

\begin{tabular}{|c|c|c|c|c|c|c|}
\hline No & Merek & Tipe & Versi OS & Instalasi & $\begin{array}{c}\text { Kualitas } \\
\text { Gambar }\end{array}$ & Error \\
\hline 1 & Samsung & A21s & Android 10 & Berhasil & Sangat Baik & Tidak ada \\
\hline 2 & Oppo & A15 & Android 10 & Berhasil & Sangat Baik & Tidak ada \\
\hline 3 & Realme & Realme 3 & Android 10 & Berhasil & Sangat Baik & Tidak ada \\
\hline 4 & Vivo & Y12s & Android 10 & Berhasil & Sangat Baik & Tidak ada \\
\hline
\end{tabular}




\section{SIMPULAN}

Berdasarkan hasil pembahasan mengenai "Aplikasi Monitoring Praktek Kerja Industri Peserta Didik SMK Mutiara Bangsa berbasis Android" merupakan pengembangan sistem yang menjadi tiga (3) tahap yaitu penempatan, monitoring dan penilaian. Maka peneliti menarik simpulan dari penelitian antara lain:

1) Dengan adanya sistem ini, pengontrolan kegiatan praktek kerja industri lebih mudah dan terdokumentasi dengan baik.

2) Guru pembimbing dapat dengan mudah mengetahui kegiatan apa saja yang dilakukan oleh siswa tanpa harus sering datang ataupun bertanya kepada pihak perusahaan/du/di.

3) Mengurangi tingkat kecurangan siswa baik dari kehadiran maupun pencatatan jurnal kegiatan

4) Mengurangi tingkat kecurangan guru pembimbing dalam memonitoring kunjungan ke perusahaan/du/di.

\section{DAFTAR PUSTAKA}

Abdurahman, H., \& Riswaya, A. R. (2014). Aplikasi Pinjaman Pembayaran Secara Kredit. Jurnal Computech \& Bisnis. $8(2), 61-69$.

Bassil, Y. (2012). A Simulation Model for the Waterfall Software Development Life Cycle. 2(5), 2.

Gani, A., \& Baye, W. (2018). Sistem Informasi Praktek Kerja Industri Pada SMK Islam Sirajul Huda Paok Dandak. Jurnal Manajemen Informatika Dan Sistem Informasi, 1(1), 52. https://doi.org/10.36595/misi.v1i1.18

Gudda, P. (2011). A Guide To Project Monitoring \& Evaluation. United State of America.

Nana Syaodih Sukmadinata, A. \&. (2010). Pengembangan Model Pembelajaran Terpadu Berbasis Budaya Untuk Meningkatkan Apresiasi Siswa Terhadap Budaya Lokal. Jurnal Cakrawala Pendidikan, 2(2), 189-203. https://doi.org/10.21831/cp.v2i2.339

Ningsih, P. W., Lusiani, T., \& Nurcahyawati, V. (2012). Rancang Bangun Sistem Informasi Praktek Kerja Industri Berbasis Web. Jurnal Sistem Informasi Komputer Akuntansi, 1(1).

Putra, D. A., Arwan, A., \& Rusdianto, D. S. (2019). Pengembangan Sistem Pengelolaan Praktik Kerja Industri pada Sekolah Menengah Kejuruan ( Studi Kasus: SMK PGRI 3 Malang ). Pengembangan Teknologi Informasi Dan Ilmu Komputer, 3(5), 4942-4950.

Safaat, N. (2011). Pemrograman Aplikasi Mobile Smartphone dan Tablet PC Berbasis Android. Informatika Bandung. In Android.

Sugiyono. (2012). Metode Penelitian Kuantitatif, Kualitatif dan R \& D. Bandung: Alfabeta.

Yudhanto, Y. \& W. A. (2018). Mudah Membuat dan Berbisnis Aplikasi Android dengan Android Studio. In Kompas Gramedia. 